\title{
Overview of Nurses Perception about Caring Based on Technology in the ICU and ER of Jember Regional Hospitals
}

\section{Nur Rohmawati ${ }^{*}$, Anisah Ardiana², Kholid Rosyidi Muhammad Nur ${ }^{3}$}

${ }^{1}$ Nursing Faculty, University of Jember, Indonesia; nurrohma2910@gmail.com (Corresponding Author)

2,3Fundamental of Nursing Department, Nursing Faculty, University of Jember, Indonesia

\begin{tabular}{|c|c|}
\hline Article Info: & ABSTRACT \\
\hline Submitted: & Caring in acute and critical care rooms has a more complex and dynamic nature due to \\
\hline 24-08-2021 & unstable patient conditions and requires more attention from nurses. Nurses \\
\hline Revised: & technological competence represents their caring based on nursing science practice. \\
\hline 13-10-2021 & This study aimed to find out how nurses perception of caring based on technology in \\
\hline Accepted: & the Intensive Care Unit and Emergency Room in Jember Region. This study used a \\
\hline 03-11-2021 & $\begin{array}{l}\text { quantitative method based on a descriptive survey. This study used a total sampling, } \\
\text { with a total of } 47 \text { nurses as respondents. The researcher used a demographic } \\
\text { questionnaire and modification of caring attribute, professional self-concept, and } \\
\text { technological influence scale to collect data. In this study, univariate analysis was }\end{array}$ \\
\hline DOI: & applied to analyze the data. The median score was 68 , as the scores approach the \\
\hline https://doi.org/10.53713/nhs.v1i3. & $\begin{array}{l}\text { maximum score of } 76 \text {. This study demonstrates that nurses have a good perception } \\
\text { toward caring based on technology. The conclusion on this study is nurses perception } \\
\text { of caring based on technology are generally positive. To further improve nurses } \\
\text { perceptions of caring expressed through technological competence, the researcher }\end{array}$ \\
\hline (c) (i) () & ence in order to provide better care and caring to patients. \\
\hline
\end{tabular}

This work is licensed

under CC BY-SA License.

Keywords: caring based on technology; nurses; perception

\section{INTRODUCTION}

Caring in acute and critical care rooms has a more complex and dynamic nature due to unstable patient conditions and requires more attention from nurses (Biswas et al., 2016; Lukmanulhakim et al., 2019). Acute and critical care environments concentrate physiological needs and employ a variety of medical treatments and interventions, putting a high demand on technological competency from health practitioners (Locsin, 1999). Nurses who treat patients with unstable conditions require the presence of technology in order to provide intense care and monitor patients closely (Anggraeni and Ismail, 2018).

The involvement of technology in nursing has been reviewed by Leininger (1988), which states that technology can eliminate the essence of caring in nursing, allowing nurses to be uncaring towards patients due to an excessive reliance on technology (Leininger, 1988; Biswas et al., 2016). However, according to Locsin (2005) technological competence that supports nursing practice is important for gaining a more comprehensive picture of the patient's condition. As a result, being technologically competent is being caring in nursing (Betriana et al., 2020).

The presence of technology can be used as an instrument to focus care in understanding the patient as a whole at that time as a form of expression of caring for nurses (Locsin, 2016). The increased speed of technological development must be balanced with an increase in nursing technological competence. It will affect to the caring of nurses in providing comprehensive care if it is not accompanied by the capacity and skills to operating medical and health technology (Yuliati and Widayanti, 2020)

The attitude and perception of nurses toward technology in nursing care is one of the factor that influences their caring in the critical care unit (Anggraeni and Ismail, 2018). The perception of technical competence as a type of nursing care is crucial to investigate because it may be used to assess humanistic care and attempts to promote patient wellbeing in high-technological settings. In Jember Region, East Java, several government-owned hospitals were reported to have health technology with good predicate and employee satisfaction in previous research (Putra and Siswanto, 2016). However, little study has been done on nurses perceptions of caring in the context of acute and critical care in hospitals. 
Based on the background description, the researcher is interested in doing research on how nurses perceived caring based on technology in intensive care unit and emergency rooms in Jember Region hospital.

\section{METHOD}

This research is a quantitative non-experimental research with a descriptive survey approach. Data were collected in July 2021 with nurses who work in ICU and ER at two government hospital in the Jember, East Java. There are 47 nurses at the time of data collection. This study using a total sampling with a total of 47 nurses as respondent that qualify inclusion and exclusion criteria set by the researcher. The socio-demographic questionnaire and modification of caring attribute, professional self-concept, and technological influence scale was used to collect data. Data were analysed using univariate analysis including median, modus, percentiles and range score (minimum-maximum) for analysis of descriptive data. This research has received ethical approval from the Health Research Ethics Commission of the Faculty of Nursing, University of Jember with the number 103/UN25.1.14/KEPK/2021.

\section{RESULT}

\section{Nurses Characteristic}

Table 1. Demographic of the Nurse $(n=47)$

\begin{tabular}{lcc}
\hline \multicolumn{1}{c}{ Characteristics } & Frequency & Percentage \\
\hline Age (year) & & \\
$26-35$ & 24 & 51.1 \\
$36-45$ & 28 & 38.3 \\
$46-55$ & 5 & 10.6 \\
\hline Formal Education & & \\
Nursing Diploma & 32 & 68.1 \\
Bachelor of Nursing & 3 & 6.4 \\
Nurse Professional Education & 12 & 25.5 \\
\hline Length of Work (year) & & \\
1-5 & 12 & 25.5 \\
6-10 & 9 & 19.2 \\
$>10 \quad$ Total & 26 & 55.3 \\
\hline \multicolumn{2}{c}{}
\end{tabular}

The study recruited 47 nurses as respondent. The findings illustrated that nurses in the ICU and ER, who participated in this study were mostly in the early adulthood with range of $26-35$ years (51.1\%). Based on formal education, most of the nurses completed their education at the nursing diploma degree (D3) $(68.1 \%)$, nursing professional education program $(25,5 \%)$, and bachelor of nursing $(6,4 \%)$. Most of the nurses have a long work experience as a nurse for more than 10 years $(55.3 \%)$.

\section{Nurses' Perception about Caring Based on Technology}

Table 2. Nurses' Perception about Caring Based on Technology ( $n=47)$

\begin{tabular}{cccc}
\hline Variable & Median $\left(\mathrm{P}_{25}-\mathrm{P}_{75}\right)$ & Mode & Min-Max \\
\hline $\begin{array}{l}\text { Perception about Caring } \\
\text { Based on Technology }\end{array}$ & $68(58-72)$ & 72 & $43-74$ \\
\hline
\end{tabular}

According to table 2, the general description of nurses' perceptions of technology-based caring has a median score of 68 , with a percentile 25 - percentiles 75 of 58 to 72 , The results of the total score respondents filling out surveys has a minimum range of 43 and a maximum range of 74 , with a score of 72 appearing frequently. In this situation, the median score of 68 was close to the maximum score of the entire questionnaire score of 76 . This result indicating that nurses' perception toward caring based on technology are in good category.

Table 3. Score for Each Indicator of Nurses' Perception of Caring Based on Technology $(n=47)$ 


\begin{tabular}{lccc}
\hline \multicolumn{1}{c}{ Indicator } & Median $\left(\mathrm{P}_{25}-\mathrm{P}_{75}\right)$ & Mode & Min-Max \\
\hline Caring attributes & $22(20-24)$ & 72 & $43-74$ \\
Technological Influence & $46(39-48)$ & 48 & $27-52$ \\
\hline
\end{tabular}

According to table 3 , in the caring attribute indicator, there are three sub-indicators such as theoretical perspective, practical perspective, and pedagogical perspective. The median score of the caring attribute indicator is 22 , from the percentiles 25 - percentiles 75 of 20 to 24 . The range of scores from the respondents in filling out the questionnaire has a mode score of 22 , and the minimum score is 14 and the maximum score is 24 . It can be concluded that nurses' perceptions of caring based on technology in the indicators of caring attribute are in good category. The indicators of the technological influence in nursing, the median score was 46 from the percentiles 25 - percentiles 75 of 39 to 48 . The range score for filling out the questionnaire from the respondents had a mode score of 48 , and the minimum score range obtained by respondents was 27 and the maximum score of 52 . Based on these results, it can be concluded that nurses perceptions of caring based on technology in the indicators of the technological influence in nursing are in good category.

\section{DISCUSSION}

\section{Nurses Characteristic}

Nurses in the Intensive Care Unit (ICU) and Emergency Room (ER) are mostly between the ages of 26 and 35 . The nurses have also completed their nursing studies at the diploma level and have more than 10 years of experience as a nurse. In this survey, most of the nurses were in their early adulthood, had good perceptions of technological competence. Age is the one of the significant factor in nurses self-assessment of their perceived level of competence (Salonen, 2007). Workers' age will increase their technological experience as well as their technical expertise of their sector of work. The findings of this study are in line with Ozan's research (2020), which indicated that the majority of hospital workers, particularly in clinical care, critical care units, operating room, and emergency room are between the ages of 25 and $34(48 \%)$ and have a positive perceptions regarding the use of technological devices in nursing care practice. This study is also in line with the previous study of Biswas, et al (2016), where the majority of respondent in this study earned a diploma degree. Nurses education levels in high degree should have high perception on caring because of high quality of knowledge may affect in changing attitude on developing their skill or knowledge (Rizany, 2018). From the researcher's point of view, the increasing age and expertise with technology that is utilized every day in the ICU and ER causes them to maintaining up-to-date care in nursing discipline, so they have a positive perception of caring and technology.

\section{Nursess Perception about Caring Based on Technology}

In this study, a higher percentage of nurses' agreement on nurses have to demonstrate their caring through their professional competence. These findings are similar with the study of Anggraeni (2018), which argues that nurses require technological competence as an addition in nursing care process in order for nurses' view technology positively and demonstrate their competence. The findings of this study on nurses caring attribute indicators revealed that nurses had positive perception on theoretical, practical, and caring pedagogical of caring. These findings suggest that, according to theoretical of caring, nurses believe that caring is a collaborative effort between nurses and patients. According to practical perspective, nurses state that competent nurses are nurses who respect themselves, nursing profession, and their patients. Whereas from a pedagogical perspective, nurses express their agreement about nurses learn caring via personal experience.

In this study, the majority of nurses had the perspective that caring is a joint effort of the nurse and the patient in achieving nursing care goals. The findings of this study on the caring attribute from a theoretical perspective are align with theory of Nursing as Caring, which describes caring as an authentic and intentional presence between nurses and their clients (Smith and Parker, 2015). The priorities in nursing care activities could change to the patients' and nurses' goals (Akansel, 2020). The researcher assumes that nurses in the ICU and ER have a good theoretical perspective because there is constantly interaction between nurses and patients as well as with the patient's family even in an emergency situation. Nurses contact and share their caring with patients and families more intensive than the other professions. Because of that, caring of nurses is a genuine experience that nurses have with their patients that cannot be replicated by other health workers.

The satatement that received approval from all nurses who participated in this study is "Competent nurses are nurses who respect themselves, nursing profession, and their patient". The practical perception of nurses attribute in this 
study is similar with nursing metaparadigm of Technological Competency as Caring in Nursing Theory, which states that the caring component is the practice of intentionality, which is seen as a situation in humans value and regulate caring relationships with themselves, the environment, and the universe (Biswas dkk., 2016). Nursing care not only limited on the technical aspect, it is a profession that require of technical and psychological skill to treating the patient comprehensively (Akansel, 2020). Nurses role in this context is to assist their patients achieve their health goals through therapeutic interventions. According to the researcher's point of view, nurses in the ICU and ER have unique procedures that oriented toward saving lives and meeting patients physiological needs, therefore nurses may perceive that caring can be expressed through their professional skill. In addition, nurses also engage in intraprofessional and interprofessional collaboration activities in accordance with existing law in order to patients' recovery, the dignity of nurses and nursing profession.

The caring attribute of nurses is seen from a pedagogical perspective, the majority of nurses agree that caring is learnt through personal experience. This study findings are similar to Albinsson's research (2018) with a sample of nursing student and lecturer in a clinical learning model, with the results of knowledge about health and caring beginning with personal experiences (Albinsson, et al., 2019). This study findings are dissimilar with the study of Salonen (2007), who found competence are learned in the clinical setting. The biggest influence on nurses' competence development are good atmosphere on the ward and encouraging style of management (Salonen, 2007). Learning that occurs after a circumstance has occurred is a suitable model for human life. When nurses put what they have learned into practice, the gap between thinking and practice getting smaller, which can be used as reflection material (Dahlberg, et al., 2009). The researcher assumes that nurses caring in the ICU and ER have the belief that caring can be learned by nurses through personal experience due to the dynamic conditions of the ICU and ER treatment rooms. This can lead to specific instances in which nurses will recall and adapt their thoughts to hospital standard operational procedures.

Nurses perceptions of practice perspective in this study show that they have a positive attitude toward the influence of technology in nursing. The study's findings are in line with Ozan's research (2020) which states that some nurses have positive perceptions or express their agreement that technological devices have a positive impact on their work and technology is an object that integrated with nurse practice (Ozan dan Duman, 2020). Nurses in critical care rooms require advanced skills and knowledge in applying increasingly advanced technology so that they can focus more on the core of caring for nurses. Caring assumptions that emphasize nursing practice that focuses on knowing patients and offering more comprehensive care through demonstration of professional skills and technology (Anggraeni dan Ismail, 2018). Researchers assume that nurses positively perceive the use of technology in nursing due to the large number of patient care activities that use and through technology and determine patient care priorities. This allows nurses to know the patient's condition better and provide more comprehensive care.

\section{CONCLUSION}

The findings of this study showed that nurses perception regarding caring based on technology was in good category. Based on the perspective of theory, practice, and pedagogy and technology in nursing practice, thus suggest that all nurses had a good perceptions or thoughts about caring based on technology. This study is expected to be able to contribute the enlighment of nurses' perceptions of caring that demonstrate using technological competence. However, program for supporting positive approach of nurses regarding of caring attributes and use of technology on their practice must be improvement. Continuing education and training sessions can provide a guidance of using technology among nurses in the critical care and emergency department.

\section{ACKNOWLEDGEMENT}

The authors thank all nurses who kindly participated in the study and everyone involved in the licencing process who made this research possible. 


\section{REFERENCES}

Akansel, N., R. Watson. (2020). Nurses Perceptions of Caring Activities in Nursing. Nursing Open, 8, 506:516.

Albinsson, G., C. Elmqvist, \& U. Hörberg. (2019). Nursing students' and lecturers' experiences of learning at a university-based nursing student-run health clinic. Reflective Practice, 20(4), 423-436.

Anggraeni, L. \& S. Ismail. (2018). Pengalaman Perawat tentang caring berbasis teknologi pada pasien kritis di intensive care unit. Jurnal Perawat Indonesia, 2(2), 70-77.

Betriana, F., T. Tanioka, R. C. Locsin, H. Malini, \& D. P. Lenggogeni. (2020). Are indonesian nurses ready for healthcare robots durin $g$ the covid-19 pandemic? Belitung Nursing Journal, 6(3), 63-66.

Biswas, S. R., W. Kongsuwan, \& Y. Matchim. (2016). Technological competency as caring in nursing as perceived by icu nurses in bangladesh and its related factors. Songklanagarind Journal of Nursing, 36(1), 1-20.

Dahlberg, K., L. Todres, \& K. Galvin. (2009). Lifeworld-led healthcare is more than patient-led care: an existential view of well-being. Medicine, Health Care and Philosophy, 12(3), 265-271.

Kartal, Y. A. (2017). Health technologies and reflections in nursing practices. International Journal of Caring Sciences, 10(3), 17331740.

Locsin, R. C. (1999). Development of an instrument to measure technological caring in nursing. Nursing \& Health Sciences, 1(1), $27-34$.

Locsin, R. C. (2016). The theory of technological competency as caring in nursing : guiding nursing and health care, 72(5), 163-170.

Lukmanulhakim, L., A. Afriyani, \& A. Haryani. (2019). Caring efficacy and nurse caring behavior in taking care of critical patients. Jurnal Ners. 14(1):55.

Ozan, Y. D. \& M. Duman. (2020). Nurses perceptions regarding the use of technological devices in nursing care practices. International Journal of Caring Sciences, 13(2), 901-908.

Rizany, I., T. S. Hariyati, \& H. Handayani. (2018). Factors that affect the development of nurses competencies: a systematic review. Enfermería Clínica, 28, 154-157.

Salonen, A. H., M. Kaunonen, R. Meretoja, \& M. T. Tarkka. (2007). Competence profiles of recently registered nurses working in intensive and emergency settings. Journal of Nursing Management, 15(8), 792-800.

Smith, M. C. \& M. E. Parker. (2015). Nursing Theories and Nursing Practice. 4th edition. Philadelphia : FA Davis Company.

Yuliati, I. dan M. R. Widayanti. (2020). Hubungan kemampuan menggunakan teknologi keperawtaan dengan caring mahasiswa profesi ners di sekolah tinggi ilmu kesehatan wilayah surabaya. Jurnal IImiah Keperawatan, 6(2), 232-243. 